The weight of the original roadway was-

Wood work,

Cast iron about ditto, - _ _ _

Wrought iron in the suspending rod, -

Gravel concrete,

$$
\text { Total, }
$$

Tons. Cwt.

690

- 920

129

$30 \quad 0$

Or 23 tons less than the new roadway.

Cost.-The platform described is 412 feet long, and 27 feet wide; it cost $\mathscr{\&} 4026$ or about 7 s. 3 d. per superficial foot.

The works were completed in the summer of 1840; the bridge has borne without injury the gales of the last winter; and the stiffness of the platform has given confidence in its strongth to all who have examined it.

Civ. Eng. \& Arch. Jour., Oct., 1841.

Experiments for determining the position of the Neutral Axis of rectangular Beams of Cast and Wrought Iron and Wood, and also for ascertaining the relative amount of compression and extension at their upper and under surfaces, when subjjected to transverse strain. By Josexir CoLThinst.

These experiments were undertaken in consequence of the differcnce of opinion which has long existed respecting the position of the neutral axis of extension and compression of iron and wood.

First experiment.-Two series of experiments were made to determine this point by cutting through the centre of each of a set of eight girders, each six feet six inches long, five inches deep, and half an inch thick, the first to the depth of half an inch, the second to the depth of one inch, and so on, to the eighth girder, in which only one inch of metal remained unsevered. The spaces cut out were then filled with carefully fitted wrought iron keys, and the girders were broken by the application of weights, in the expectation that those weights would be some indication of the neutral point of each girder. The results were, however, so irregular, that no satisfactory deductions could be drawn from them.

Second experiment.-The next attempt was made in the manner suggested by the late Mr. 'Tredgold, by drawing two finc lines, two and three-fourths inches apart, on a polished surface, at right angles to a girder, in the middle of its length; it was then subjected to strain, and dimensions were sought to be taken to determine where their divergence and convergence commenced, but the differences were too small to be susceptible of accurate determination, othcrwise than by a fine micrometical operation, which at the time the author had not an opportunity of applying. The following plan was therefore adopted:

Third experiment.-In the side of a cast iron girder, six feet six inches long, seven inches deep, and one inch thick, a recess was planed at the centre, three inches wide by a quarter of an inch deep. This was filed up very true, and $\mathbf{1 4}$ small bars of wrought iron, with coni- 
cal ends, were placed in it at regular distances of half an inch apart. 'These bars were of such lengths as to hold sufficiently tight to carry their own weight, and yet that the slightest touch should detach them. The girder was then subjected to strain. The supports were six feet apart; with a strain equal to 100 pounds, the lower bar fell out; as it was increased, they continued to drop, and with 1500 pounds, all those below the centre had fallen. The strain was then increased to 7000 pounds, but no more bars fell. The centre bar remained exactly as when put in; all those above the centre became firmly fixed, and were evidently under considerable compressive force. The strain was then gradually taken off, and all the bars above the centre fell out, their ends having become compressed by the sides of the recess pressing on them; they were, of course, too short when the girder resumed its former condition, and the recess its previous width. These experiments were repeated several times, with pieces of fine wire and dry lance-wood charred at the ends.

'The result in cvery case showed that the neutral axis of extension and compression was cortainly situated within $\frac{2}{10}$ of an inch of the centre.

Another experiment was still more decisive. A girder nine feet six unches long, eight inches deep, one inch thick, was cast with two brackets or projections on the side, each nine inches on either side of the centre. A brass tube bar, with circular ends and a sliding adjustment, was fixed between the brackets, which had been filed true. 'The clear bearing was seven feet six inches; a strain of fifty pounds was sufficient to cause this bar to drop out; and with 250 pounds the whole effect of the previous experiment was produced. The tube, when placed loosely, one inch above the centre, was held fast by a strain of 1000 pounds.

Wrought Iron.-Cimilar experiments were then made on wrought. iron, with precisely the same results, showing that the neutral axis, if not actually situated at the centre, was nearly identical with it.

Wood.-A similar series of experiments, made upon wood beams, gave exactly the same results as regarded the position of the neutral axis.

From all the foregoing experiments, the author concludes that the neutral axis of extension and compression in rectangular beams of cast and wrought iron and wood, is situated at the centre of their depth, when those beams are subjected to transverse strains.

Extension and compression. Cast Iron.-Experiments were also institutod to ascertain the amount of extension and compression of cast and wrought iron and wood.

Upon a bar of cast iron, three inches square, and nine feet long, two strips of thin hoop iron were attached, the one on the upper, and the other on the lower side, each strip being fastened to the bar at one end only, while the other end was left free; any change which occurred in the length of the surface to which it was applied was clearly indicated. The differences were recorded by very fine lines on a polished surface. The strips were seven feet six inches long, and were bound to the whole length of the beam by bands of fine wire, 
wound round and enclosing them at every nine inches; the beam was then subjected to strain, and the following results wore obtained:-

$\begin{array}{cccc}\begin{array}{c}\text { Weight. } \\ \text { Ib. }\end{array} & \begin{array}{c}\text { Deflection. } \\ \text { inches. }\end{array} & \begin{array}{c}\text { Compression. } \\ \text { inches. }\end{array} & \begin{array}{c}\text { Extension. } \\ \text { inches. }\end{array} \\ 1000 & 0.22 & . .04 & . .04 \\ 2000 & 0.45 & 0.04 & .042 \\ 3000 & 0.65 & 0.08 & 0.06 \\ 4000 & 0.87 & 0.11 & 0.08 \\ 5000 & 1.20 & 0.13 & 0.12 \\ 6000 & 1.50 & 0.14\end{array}$

6240 the beam broke; good iron, showing a good clear fracture. It will be perceived, that until rather more than two-thirds of the breaking weight was put on, the arnounts of extension and compression did not sensibly differ, but between that point and the breaking weight, cxtension yielded in a higher ratio than compression.

Wrought Iron.-Similar experiments were next made on bars of wrought iron, two and a half inches square; the supports were thirteen feet six inches apart, and the strips of hoop iron were twelve feet long.

Weight. Deflection. Compression. Extension. Elasticity.

$\begin{array}{rcccc}\text { lbs. } & \text { inches. } & \text { inches. } & \text { inches. } & \text { impaircd. } \\ 500 & 0.55 & 0.03 & 0.03 & . . \\ 1000 & 1.55 & 0.06 & 0.06 & . . \\ 1280 & 1.45 & 0.07 & 0.07 & 0.15 \\ 1560 & 1.85 & 0.08 & 0.05 & . . \\ 1800 & 2.20 & 0.09 & 0.09 & . \\ 2000 & 2.70 & 0.11 & 0.11 & 0.65 \\ 2280 & 4.15 & 0.18 & 0.19 & 2.05\end{array}$

With this weight the beam was permanently bent, and its elasticity nearly destroyed.

These experimonts showed that, differing from cast iron, the amounts of extension and compression in wronght iron continue to be equal up to the complete destruction of the elasticity of the beam.

Fir battens. - The amounts of extension and compression in rectangular beams of fir timber, when subjected to transverse strain, were next determined; the manner of proceeding was precisely the same as in the preceding experiments.

A batten, four inches by thrce inches, with the supports cight feet two inches apart, and with strips seven feet six inches long, when subjected to transverse strain, gave these results:-

$\begin{array}{cccc}\text { Weight. } & \text { Deflection. } & \text { Comprossion. } & \text { Extension. } \\ \text { ilb. } & \text { inches. } & \text { inches. } & \text { inches. } \\ 500 & 1.10 & 0.12 & 0.12 \\ 1000 & 2.30 & 0.24 & 0.24\end{array}$

Results.-From these experiments on the amount of extcosion and compression of cast iron, measured at the upper and under surfaces of rectangular beams, subjected to transverse strain, the author assumes, that within limits which considerably exceed those of elasticity, and equal to at least two-thirds of the breaking weight, there is no sensible difference between the amounts of compression and extension, and that 
as the breaking point is approached, extension yields in a higher ratio than compression, and gives way first.

It would appear certain that up to the point when the elasticity of wrought iron is completely destroyed, and the beam is bent, the amounts of compression and extension continue exactly equal, and it is therefore probable that this equality would continue to the last.

It is clear that the amounts of extension and compression up to threc-fourths of the breaking weight do not sensibly differ in fir battens, but that as the ultimate strength of the beam is approached, compression yields in a much higher ratio than extension and may be actually seen to give way first.

Hc states also, that the amounts of extension and compression are in dircet proportion to the strain, within the limits of elasticity and that even after those limits are greatly exceeded, and up to threefourths of the strength of a beam, they do not sensibly differ.

Ibid

\section{㼛echanics, Hegister.}

\section{LIST OF AMERICAN PATENTS WHICH ISSUED IN DECENBER, 1S4C}

With Remarls and Exemplifications by the Editor.

1. For Forming Dovetailed, or Oblique, Catches, or projections, an plates cast from iron or other metal; Jordan L. Mott, City of $\mathrm{New}$ York, December 1.

The patentee says-"These catches or projections are such as are required and used for holding latches, the retaining of stove feet, dovetailed wedges on railroad chairs, and for a variety of purposes similar in character, and well known to founders. The ordinary mode of forming projections for the catches to latch, or retain in place, the doors, or other parts of stoves, and of forming the dovetailed grooves for recciving and retaining the legs of stoves, and of producing projections on cast articles for numerous other purposes, has been by the use of sand cores, or of movable pieces on the pattern, which pieces are taken from the mould after the removal of the main plate, or piece of casting. Instead of employing these, or similar devices, I make holes through the pattern in the part where such projections are to be formed, or through a plate, or piece of metal, or of wood, which may be laid upon the proper part of the monld after the main pattern has been removed, and through these holes I force a punch, or piece, adapted thereto, which is to be so formed as to make an impression in the sand of the exact form required, by which means said impression will be produced with much greater facility and truth than by any of the methods heretofore used or known."

"I am aware that it is a common practice among founders to form depressions in the sand by pricking through holes made in the patterns for that purpose, so as to produce pins, or, shanks, on the casting to be obtained, and I do not therefore claim the so doing as of my in- 